\title{
"Followership" - The Missing Puzzle in Educational Leadership Research
}

Yeo Siew Pey, Abdul Halim Busari, Lee Jun Choi, and Zaiton Hassan

To Link this Article: http://dx.doi.org/10.6007/IJARBSS/v11-i2/9188

DOI:10.6007/IJARBSS/v11-i2/9188

Received: 17 December 2020, Revised: 19 January 2021, Accepted: 31 January 2021

Published Online: 22 February 2021

In-Text Citation: (Pey et al., 2021)

To Cite this Article: Pey, Y. S., Busari, A. H., Choi, L. J., \& Hassan, Z. (2021). "Followership" - The Missing Puzzle in Educational Leadership Research. International Journal of Academic Research in Business and Social Sciences, 11(2), 904-923.

Copyright: (c) 2021 The Author(s)

Published by Human Resource Management Academic Research Society (www.hrmars.com)

This article is published under the Creative Commons Attribution (CC BY 4.0) license. Anyone may reproduce, distribute, translate and create derivative works of this article (for both commercial and non-commercial purposes), subject to full attribution to the original publication and authors. The full terms of this license may be seen at: http://creativecommons.org/licences/by/4.0/legalcode

Vol. 11, No. 2, 2021, Pg. 904 - 923

Full Terms \& Conditions of access and use can be found at http://hrmars.com/index.php/pages/detail/publication-ethics 


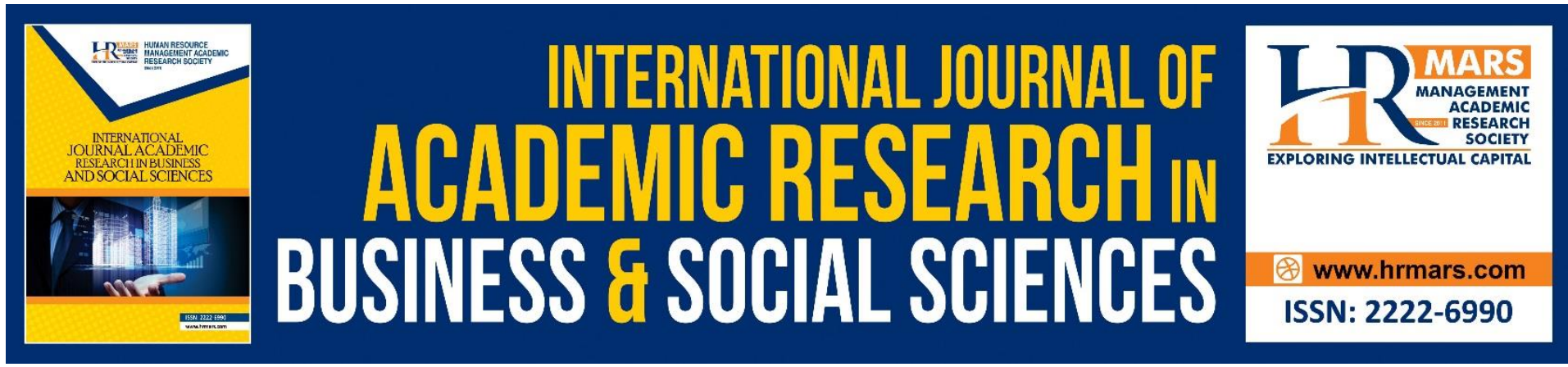

\title{
"Followership" - The Missing Puzzle in Educational Leadership Research
}

\author{
Yeo Siew Pey, Abdul Halim Busari, Lee Jun Choi, and Zaiton \\ Hassan
}

Faculty of Cognitive Sciences and Human Development, Universiti Malaysia Sarawak, 94300 Kota Samarahan, Sarawak, Malaysia

\begin{abstract}
Over the past three decades, many scholars have begun to view followers as assets in understanding leadership. However, limited studies have explored the potential impact of followership on educational leadership, particularly in school settings. Therefore, the goal of this paper is to review the teachers' followership styles in literature from 1997 to 2018 in school settings with reference to the Kelley Followership Model. The findings have shown that most of the teachers are categorised as exemplary followers. This group of teachers acquired high scores in independent critical thinking skills and are actively engaged in school activities. Exemplary teachers may equip schools to improve and sustain their performance. Good followership can be strengthened by dyadic relationships between leaders and followers. This relationship is imperative as it shapes the development of pragmatic strategies that help to promote leadership effectiveness. The results benefit both school leaders and teachers in recognizing the value to cultivate a dignified leader-follower relationship.
\end{abstract}

Keywords: Followership, Followership Styles, Educational Leadership, School, LeaderFollower Relationship

\section{Introduction}

Over the past three decades, followership proposition started to penetrate the monopoly of leadership conceptional literature. Among the limited leadership study that referred to followers, Gronn \& Ribbins (1996) for instance, affirmed the role of followers when they mentioned methodologies, such as ethnography and biography. However, Gronn (1999) failed to convince the people to recognise the role of followers in the leadership process despite the attempts to promote follower-centric leadership in his book. Till date, the empirical evidence based on followership-centric research is relatively small and inadequate (Carsten et al., 2016; Foti et al., 2017), especially in the educational leadership field (Crippen, 2012; Francis, 2015; Thody, 2003). There are limited studies that explored the potential impact of followership on educational leadership, particularly in school settings. This knowledge gap has warranted ongoing research efforts in educational followership field. Therefore, the purpose of this paper is to illustrate the teachers' followership styles in school settings. 


\section{Definition of Followership}

Robert E. Kelley (1992), one of the pioneer scholars in followership research, defined the term "followers" from its etymological roots - "follaziohan", an Old High German word that means "being able to help or assist" in the $9^{\text {th }}$ and $11^{\text {th }}$ centuries. Kelley (1992) defined the term "followers" as "People who know what to do without being told. People who act with intelligence, independence courage, and a strong sense of ethics" (p.1). Kelley's (1992) description on followers indicates that he perceived followers as proactive, having their own thoughts on doing things and being ethical. In the same vein, Kellerman (2008) also argued that subordinates do not merely follow all the time but perceived themselves as free agent instead of dependent subordinates. Adopting a similar position, Chaleff (2008) and Ghias and Hassan (2018) also hold the view that followers are not merely subordinates. They stated that followers refer to those who are able to understand, influence and contribute to accomplish the purpose and vision of their leaders and organization.

In general, the evolution of followership literature has discovered three common concept definitions. First, followership is characterised as a construct that is independent of leadership and involves the identification of followers' individual characteristics. Second, followership is illustrated as a relationship of cause and effect within leadership process. Third, followers are recognized as asset to understand leadership. The specific details of these three interpretations are discussed below.

The initial stage of followership studies aimed to define followership as independent of leadership and involve the identification of followers' individual characteristics. From this stance, it is understood that many followers hold the capacity and desire to argue the concept of a leader as well as to propose their own. In accordance with that claim, Kilburn (2010) accepted that followers had the option of who, when and how to follow. Eventually, prominent follower scholars such as Chaleff (2008), Kellerman (2008) and Kelley (1988) began their followership research with a focus on defining the individual characteristics of followers. For example, Kelley (1988) developed his followership model by measuring the level of independent critical thinking and active engagement of followers. In the same vein, Chaleff (2008) argued that followers are not passive subordinates but brave enough to criticise the misconduct or wrongdoing of their leaders. Thus, Chaleff (2008) classified followers by their level of support and courage to challenge the leaders. Taking a follower-centric lens, Kellerman (2008) also has predicted that good followers will be agents of change that determine the success of organisations alongside with the exposure they are currently gaining through advanced technology.

Apart from that, followership is illustrated as a relationship of cause and effect within leadership process. The evolution of the concept exhibits how interdependence underlying development of leadership and followership. In a recent literature, Warfield et al. (2019) demonstrated leadership and followership roles as the Chinese principles, Yin and Yang, which representing duality yet harmonious relationships. Although many studies have focused on how this relationship emerge within leaders and followers and then serve organizational missions, however, Crossman and Crossman (2011) revealed in their literature review that definitions of followership, regardless of discipline, were biased to leader-centric and constructed in terms of how the concept related to leadership. Therefore, Crossman and Crossman (2011) revamped with the following definition: "Followership is a relational role in which followers have the ability to influence leaders and contribute to the improvement and attainment of group and organizational objectives" (p. 484). 
Meanwhile, the third standpoint recognized followers as an asset in understanding leadership. Researchers noticed both leaders and followers share common characteristics such as initiative, self-control, commitment, honesty, credibility, courage and working well with others (Kelley, 1988) upon exploring the relationship between leader and follower in the leadership process. Such disclosure has led to the confusion surrounding these two roles. Most of the time, leaders and followers work together to achieve common goals, but they are ironically assumed different roles along the process. In addressing this confusion, Carsten et al. (2010); Clarke et al. (2015) somehow gave similar explanation to the phenomenon by suggesting both roles are dynamic whereby individuals may shift roles when required to achieve desired outcomes. Given that future leaders will come from the pool of individuals currently serving as followers, it is therefore equally important to recognize leadership and followership as a significant symbiotic relationship between those who lead and those who choose to follow.

To conclude, followership should be understood as a crucial building block in the leadership process. Kelley (1992), the prominent scholar in the followership field, affirmed: "Followers determine not only if someone will be accepted as a leader but also if that leader will be effective" (p.13). Therefore, leaders and followers need to work together synchronously in order to make things happen. Good followers know when and how to align themselves with the goals of the organizations. They recognize their possible effect on the success or failure of the organizations. Likewise, they are perfectly honest about their shortcomings and limits. On the basis of transparent, truthful, and effective communications, followers can establish strong and sincere relationships with their leaders. This productive reciprocal relationship is embarked more by mutual respect than by formal authority and hierarchy. Such a stable relationship is the cornerstone of an organization's success which demonstrates leadership effectiveness. In these ways, followers become a driving force for their leaders and even a significant asset to the organizations.

\section{Kelley's Followership Model}

Kelley's Followership Model defines followers based on their behaviour and personality traits. In his model, Kelley $(1988,1992)$ claimed that the commitment and work output of followers are influenced by two dimensions, namely independent critical thinking, and active involvement. Kelley, therefore, designed a measuring instrument based on these two dimensions alongside with the model.

The first dimension in Kelley's Followership Model is referred to the independent critical thinking as level of followers' thinking. Followers with excellent ability of critical thinking always give constructive criticism independently and innovatively upon the issues at work. They are courageous, capable to take orders and follow the directions without creating trouble to their leaders or organizations. Conversely, the worst followers are followers who exhibit dependent, uncritical thought, as they often rely on their leaders' explicit instructions.

In Kelley's Followership Model, the other inclusive dimension is active engagement, which describes the level of engagement of followers in the organization. Followers who actively engaged are generally optimistic, show a good attitude towards others, are willing to do more than their job position and exemplify citizenship behaviour (Kelley, 1992). On the opposite spectrum, less engaged followers are only interested in getting their job done. These groups of terrible followers are lazy, passive, immoral, and required guidelines to accomplish goals. In accordance with the surveys derived in measuring the followership dimensions (i.e., 
level of critical thinking and engagement), Kelley (1992) classified followers into five different styles of followership, i.e., exemplary, alienated, conformist, pragmatist, and passive. Table 1 illustrates the characteristic of each followership style as according to Kelley (1992).

Table 1. Kelley's Followership Styles (1992)

\begin{tabular}{ll}
\hline Types of Follower & Description \\
\hline Exemplary & $\begin{array}{l}\text { Followers who are independent and able to think critically yet stay } \\
\text { engaging strongly with the group. They provide intelligent support } \\
\text { and challenge to the leader. }\end{array}$ \\
Alienated & $\begin{array}{l}\text { Followers who are independent and critical thinkers but do not } \\
\text { willingly obligate to the leader. }\end{array}$ \\
Pragmatist & $\begin{array}{l}\text { Followers who are run-of-the-mill in their independence, } \\
\text { engagement, and general contribution to the leader. }\end{array}$ \\
Conformist & $\begin{array}{l}\text { Followers who are more engage than passive followers, but do not } \\
\text { pose any particular challenge. } \\
\text { Passive }\end{array}$ \\
\hline
\end{tabular}

Extensive research has been conducted by scholars who attempted to develop numerous models of followership styles. All the proposed followership models showed some parallels in describing the behaviours and thought of followers when they interacted with their leaders in the organizations in where they served. Scholars such as Kelley (1992), Chaleff (2008), and Kellerman (2008) are among the most frequently cited in this relative field. Despite all the three models come from the corporate world, there are also subtle variations between them. For instance, Kellerman's (2008) model aims to recognize the position of followers in a leader-follower relationship that allows organizations to identify opportunities or challenges to better engage followers appropriately. Yet, both Kelley (1992) and Chaleff (2008) expressed the same concerns and efforts to raise awareness of the value of followership among followers in corporate field. However, Kelley's (1992) model emphasizes the followers' initiative (e.g., "self-starter") to engage and offer their critical ideas creatively and innovatively to benefit leaders and organizations. On the other hand, Chaleff (2008) argues that followers support only if they view themselves as a partner in a leader-follower relationship. Thus, followers only criticize the behaviour or decision of their leaders if they feel that it could undermine the objectives or values of the organizations. It is fairly obvious that in Chaleff's (2008) model, leaders are the hidden agenda behind the followers to behave in their own way.

Upon evaluating the few options, this present study chooses Kelley's (1992) Followership Models as it offers the most complete understanding of followership styles. Kelley (1992) stresses the influence and value of the follower as an exemplary follower. The level of follower engagement and their capability to think independently reflects how much they can contribute to the organizations. Therefore, Kelley (1992) ascertains the organizations should aim to turn all followers into exemplary types for their own good.

\section{Developing Followership Lexicon in Schools}

Today's schools are too complicated to be run solely by school principals. The abolition of "solo-hero" in organizations has alarmed scholars to seriously consider the essential role of followers in the leader-follower relationship (Kellerman, 2008; Kelley, 1992). In her more 
recent work, Kellerman (2016) posits that organizations have progressively adapted flat systems and eliminated hierarchies, where followers have more flexibility and opportunity to contribute to their staff and corporate strategies than ever before. Thus, there is an urgent need to cultivate the notion of followership in schools.

Angela Thody, Emeritus Professor of Educational Leadership from the United Kingdom, is a visionary in her attempts to bring followership lexicons to schools. Targeting the readers who concerned educational leadership, Thody (2000) published an article 'Followership or Followersheep? An Exploration of the Values of Non-Leaders' in Journal of Management in Education to challenge the readers in understanding the important of followership. Thody (2000, p.15) asserted that followership was 'a missing dimension in studies on effective schools' in her article. Furthermore, Thody (2000) emphasized the reasons why school leaders needed to value and nurture followers within the school context. Regrettably, Thody's notion on followership has received contentious input. The school community, including school principals, teachers, staffs, and pupils, strongly rejected adoption of the word 'follower' in school.

Despite the rejection, Thody run a simple survey among 157 academics and practitioners in a conference in 2002. As a result, Thody managed to classify followers with reference to the follower types and roles into two groups, namely 'positively effective' and 'negatively effective'. Thody (2003) managed to uncover the first followership lexicon in education via her pioneering article entitled 'Followership in educational organizations: a pilot mapping of the territory'. Apart from the limitations, Thody's research has shed light to better understand the influence of both positive and negative followers in future research. Above all, followership theory must first be understood as a role rather than a personal trait.

Given the symbiotic linkage between leadership and followership, empirical evidence revealed that followers play vital roles in the success and failure of an organization (Thody, 2003; Kellerman, 2008). For example, Cruickshank (2017) analysed the leader-follower dynamic in an Australian elementary school and demonstrated that the power of united followers has the potential to remove the bad leader. In his study, Cruickshank (2017) concluded that leaders should be alert to the demands of the followers and to be mindful of the influence that the followers possess in relation to good leadership. This "power" must always be balanced in an acceptable equilibrium to sustain a good, fulfilling and mutually beneficial relationship as well as to promote exemplary followership.

Another narrative inquiry case study on followers' role was reported by Tsakeni and Jita (2017). The study managed to gather data from 2 leaders and 4 teachers in on top performing secondary school in Bloemanda Township in the South African city of Bloemfontein. The findings provide an overview that the active identity of follower role enabled teacher to co-construct and maintain leadership process. In the same vein, Du et al. (2019) employed multiple data collection methods which involved 58 formal interview and 8 informal interviews of principals, vice principals, directors and teachers, field observations and archival data to explore the effects of followers in six Chinese schools. Du et al. (2019) discovered that although leaders tended to rule and followers tended to comply in China, followers might reject or ignore leaders and that leaders need to compromise with followers.

Adding to the literature, Clarke (2015) has carried out a mixed method study with questionnaire $(n=56)$ and semi-structured interviews $(n=4)$ of mentor teachers in Republic of Ireland. By using different level teachers as research subject, the findings of this exploratory study showed that the hierarchical nature of the school setting affected the perceptions of 
the leadership and followership roles among mentor teachers. The mentor teachers recognized that all school members may contribute to the school leadership process despite their position.

Experience and the results of the aforementioned studies have shown that teachers practice their role as followers with considerable power to positively influence the direction and make substantial contributions to the success of the schools. In fact, the role of followership among teachers can be more clearly portrayed through their styles of followership. Followership styles, in particular, rely largely on personality traits and behaviours, environmental factors, wider social settings, as well as on the current position of the organisation. Teachers in the school setting work in a professionally organised business framework and as such, presume the requirement of obedience to supervisors, their instructions, and expectations. Nevertheless, schools can also be breeding grounds for the potential negative consequences of conformist or similar degrading forms of employee behaviour (Hinić et al., 2017). In resolving this question, the distribution of followership styles among teachers in the school context needs to be examined.

At the time of undertaking the current study, only a few studies examined teachers' followership styles in school settings (see Table 2). Apart from the limited variation, researchers have also recorded inconsistent findings for the distribution of followership styles being practice in schools. Among the earliest studies in educational followership literature, Mertler et al. (1997) examined the understanding of followership among 67 public elementary and secondary teachers in the states of California and Ohio, USA. His quantitative study using Teacher Sentiment Inventory (incorporating Kelley's Followership Typology, 1992) indicated only three types of followership styles, namely exemplary, pragmatic, and conformist. Interestingly, Mertler et al (1997) found that female teachers reported higher level of active engagement in the role of follower as compare to male teachers.

Similarly, Johnson (2003) conducted a study with 102 high school teachers in Mississippi, USA as research subjects and Kelley's (1992) Followership Typology as instrument. Johnson (2003) research results revealed only two types of followers, i.e., exemplary (92\%) and conformist (8\%). However, Johnson (2003) found no difference in followers' active engagement and critical thinking skills based on gender, age, teaching experience, and time with leader. Johnson (2003) concluded her qualitative findings as followers generally reflect modalities that corresponds with the leaders' styles and behaviours.

Similar work was also carried out by Francis (2015) using Kelley's (1992) Followership Questionnaire to 69 secondary school teachers in United Kingdom to understand how teachers follow. In line with Johnson (2003); results, Francis (2015) reported that there was no association between gender or length of service of the teachers and how they enact followership. In addition, the findings revealed a minimal variety of followership styles with the dominance of exemplary followers (86\%) and pragmatic followers comprising the remaining 14\%. Likewise, Hinić et al. (2017) conducted a quantitative study employing Kelley's (1992) Followership Questionnaire, which completed by 206 secondary school teachers in Serbia, revealed the same pattern of followership styles as obtained by Francis (2015). Hinić et al. (2017) reported $58.7 \%$ of exemplary followers and $39.8 \%$ of pragmatic followers among the respondents.

Despite the majority of researchers found only two types of followership styles, Mimick (2018) disclosed four types of followership styles in reference to Kelley's (1992) Followership Typology. This more recent research aimed to examine the followership styles 
and job satisfaction among public Midwestern K-12 teachers. The findings from this research indicated the most dominant followership styles performed by teachers is exemplary (69.5\%), followed by pragmatic $(24.8 \%)$, alienated $(3.8 \%)$, and conformist (1.9\%). Surprisingly, conformist followers have reported statistically significant mean job satisfaction ratings that are lower than all other forms of followers found in this study.

In the same note, Hicks (2018) employed a mixed-method study to explore the followership theory and its practical application in New Hampshire public high schools. The study involved modified Kelley's (1992) Followership Questionnaire and two open-ended questions completed by 559 teachers. The research supported previous studies with most teachers are found to be exemplary followers (76.4\%), pragmatists (14.8\%) and conformists (8.7\%). Contradictory, the results showed that there were significant association between gender and subject matter on followership styles. Women had higher counts as conformist, while men had higher counts for the category of pragmatist. In comparison, English and Technology teachers were identified with exemplary followers, while Math teachers were identified with conformist and pragmatist styles. The qualitative findings revealed that principals support their teachers' followership role with personal interaction, giving professional support and setting up essential organizational structure. It is noteworthy to mention that there is a trend in which almost $73 \%$ of critical feedback on leaders have been registered by teachers who have served with their principals for fewer than five years.

In opposition to the Western literature's results, a local study by Al-Anshory and Mohd Ali (2014) chose 92 primary and secondary school teachers as research subject had reported all of the five Kelley's followership styles (i.e. exemplary, pragmatist, alienated, conformist and passive) were distributed at Adni Islamic School (AIS), Malaysia. Nevertheless, the most common followership style reported still being the exemplary $(42.3 \%)$, followed by pragmatist (26.1\%), conformist (16.3\%), passive (8.7\%) and alienated (6.5\%). The study also found that the followership styles of AIS male primary school teachers differed significantly from AIS secondary school teachers.

A further local study was recently conducted by Thannimalai (2020) using a qualitative approach to exploring the relationship between followership and leadership. Thannimalai (2020) employed a semi-structured interview with two Malaysian principals, one from cluster excellent primary school and another one from premier secondary school. The interview data was triangulated with observation from video recordings of the communication process between principals and teachers as well as document analysis. The research results pointed out that followership styles tend to be more significant in the school with principal who adapted a combination of directive characteristics, transactional leadership, servant leadership which depending on the situation and environment. On the other hand, the principal who practises "Laissez-faire" leadership styles delegated duties to his teachers at the beginning of the years and rarely interfered unless there are conflicts occur. Despite this "Laissez-faire" leadership style, followership was still prevailed because the school had established with its own culture as a tradition. Teachers are therefore committed to carrying out their duties, regardless of whether and how the principal behaves. This study stated that teachers are independent and have autonomy in both schools. However, the level of teachers' involvement in decision making is just average. An overall summary of the previous studies is given in Table 2. 
Table 2. Summary of the Past Findings on Teachers' Followership Styles in Schools

\begin{tabular}{|c|c|c|c|c|c|c|c|}
\hline $\begin{array}{l}\mathbf{N} \\
\mathbf{0}\end{array}$ & $\begin{array}{l}\text { Author/Year } \\
\text { /Title }\end{array}$ & Publisher & Field & $\begin{array}{l}\text { Count } \\
\text { ry }\end{array}$ & $\begin{array}{l}\text { Research } \\
\text { Purpose }\end{array}$ & $\begin{array}{l}\text { Research } \\
\text { Approach }\end{array}$ & $\begin{array}{l}\text { Findings } \\
\text { on } \\
\text { Teachers } \\
\text { Follower } \\
\text { ship } \\
\text { Styles }\end{array}$ \\
\hline 1 & $\begin{array}{l}\text { Mertler } \\
\text { (1997) - } \\
\text { Teachers' } \\
\text { Perceptions } \\
\text { of the } \\
\text { Leadership- } \\
\text { Followership } \\
\text { Dialectic }\end{array}$ & $\begin{array}{l}\text { Paper } \\
\text { presented } \\
\text { at the } \\
\text { Annual } \\
\text { Meeting } \\
\text { of the } \\
\text { Midweste } \\
\text { rn } \\
\text { Education } \\
\text { al } \\
\text { Research } \\
\text { Associatio } \\
\mathrm{n} \\
\text { (Chicago, } \\
\text { IL, } \\
\text { October } \\
\text { 15-18, } \\
\text { 1997) }\end{array}$ & $\begin{array}{l}\text { Elemen } \\
\text { tary and } \\
\text { Second } \\
\text { ary } \\
\text { School }\end{array}$ & USA & $\begin{array}{l}\text { To } \\
\text { determine if } \\
\text { public } \\
\text { teachers in } \\
\text { the states of } \\
\text { California } \\
\text { and Ohio } \\
\text { understand } \\
\text { the role and } \\
\text { importance } \\
\text { of } \\
\text { followership } \\
\text { in } \\
\text { influencing } \\
\text { school } \\
\text { leadership. }\end{array}$ & $\begin{array}{l}\text { A } \\
\text { quantitativ } \\
\text { e study } \\
\text { using a } \\
\text { questionnai } \\
\text { re, Teacher } \\
\text { Sentiment } \\
\text { Inventory } \\
\text { (incorporat } \\
\text { ing Kelly } \\
\text { (1992) } \\
\text { Followershi } \\
\text { p Typology) } \\
\text { to assess } \\
\text { the extent } \\
\text { to which } \\
\text { the } \\
\text { teacher's } \\
\text { specific } \\
\text { actions and } \\
\text { characteris } \\
\text { tics } \\
\text { reflected } \\
\text { their } \\
\text { understand } \\
\text { ing of } \\
\text { followershi } \\
\text { p. The } \\
\text { teachers } \\
\text { also ranked } \\
\text { statements } \\
\text { associated } \\
\text { with } \\
\text { particular } \\
\text { actions or } \\
\text { beliefs } \\
\text { concerning } \\
\text { the } \\
\text { relationshi }\end{array}$ & $\begin{array}{l}\text { Exemplar } \\
\mathrm{y}=\mathrm{V} \\
\text { Alienate } \\
\mathrm{d}=0 \\
\text { Pragmati } \\
\mathrm{st}=\mathrm{V} \\
\text { Conformi } \\
\mathrm{st}=\mathrm{V} \\
\text { Passive }= \\
0 \\
\\
\text { *no } \\
\text { percenta } \\
\text { ge have } \\
\text { been } \\
\text { shown in } \\
\text { the paper } \\
\text { as } \\
\text { scatterpl } \\
\text { ot of the } \\
\text { subscale } \\
\text { scores } \\
\text { (active } \\
\text { engagem } \\
\text { ent } x \\
\text { independ } \\
\text { ent } \\
\text { thinking) } \\
\text { was } \\
\text { plotted } \\
\text { and } \\
\text { examine } \\
d \text { by the } \\
\text { authors }\end{array}$ \\
\hline
\end{tabular}




\begin{tabular}{|c|c|c|c|c|c|c|c|}
\hline $\begin{array}{l}\mathbf{N} \\
\mathbf{O}\end{array}$ & $\begin{array}{l}\text { Author/Year } \\
\text { /Title }\end{array}$ & Publisher & Field & $\begin{array}{l}\text { Count } \\
\text { ry }\end{array}$ & $\begin{array}{l}\text { Research } \\
\text { Purpose }\end{array}$ & $\begin{array}{l}\text { Research } \\
\text { Approach }\end{array}$ & $\begin{array}{l}\text { Findings } \\
\text { on } \\
\text { Teachers } \\
\text {, } \\
\text { Follower } \\
\text { ship } \\
\text { Styles } \\
\end{array}$ \\
\hline & & & & & & $\begin{array}{l}\mathrm{p} \text { between } \\
\text { the teacher } \\
\text { and the } \\
\text { principal } \\
\text { ( } n=67) .\end{array}$ & \\
\hline 2 & $\begin{array}{l}\text { Johnson } \\
\text { (2003) } \\
\text { A Study of } \\
\text { the } \\
\text { Relationship } \\
\text { Between } \\
\text { Followership } \\
\text { Modalities } \\
\text { and } \\
\text { Leadership } \\
\text { Styles } \\
\text { Among } \\
\text { Educators at } \\
\text { Selected } \\
\text { High Schools } \\
\text { in Jackson, } \\
\text { Mississippi }\end{array}$ & $\begin{array}{l}\text { Unpublish } \\
\text { ed } \\
\text { doctoral } \\
\text { dissertatio } \\
\mathrm{n}\end{array}$ & $\begin{array}{l}\text { High } \\
\text { school }\end{array}$ & USA & $\begin{array}{l}\text { To explore } \\
\text { the nature } \\
\text { of the } \\
\text { relationship } \\
\text { between } \\
\text { followership } \\
\text { modalities } \\
\text { and } \\
\text { leadership } \\
\text { styles of } \\
\text { high-school } \\
\text { teachers } \\
\text { and } \\
\text { principals in } \\
\text { Jackson, } \\
\text { Mississippi, } \\
\text { USA }\end{array}$ & $\begin{array}{l}\text { A mixed } \\
\text { method } \\
\text { study: } \\
\text { Kelley } \\
\text { (1992) } \\
\text { Followershi } \\
p \\
\text { Questionna } \\
\text { ire } \\
\text { completed } \\
\text { by } \\
\text { teachers(n } \\
=102 \text { ) and } \\
\text { Multifactor } \\
\text { Leadership } \\
\text { Questionna } \\
\text { ire (MLQ } \\
\text { Form } 5 x- \\
\text { Short) } \\
\text { administrat } \\
\text { ed to } \\
\text { principals } \\
\text { ( } n=5 \text { ) and } \\
\text { semi- } \\
\text { formal } \\
\text { interviews } \\
\text { of teachers } \\
\text { ( } n=10 \text { ) and } \\
\text { principals } \\
\text { ( } n=2 \text { ). }\end{array}$ & $\begin{array}{l}\text { Exemplar } \\
y=92 \% \\
\text { Alienate } \\
d=0 \\
\text { Pragmati } \\
\text { st }=0 \\
\text { Conformi } \\
\text { st }=8 \% \\
\text { Passive= } \\
0\end{array}$ \\
\hline
\end{tabular}




\begin{tabular}{|c|c|c|c|c|c|c|c|}
\hline $\begin{array}{l}\mathbf{N} \\
\mathbf{0}\end{array}$ & $\begin{array}{l}\text { Author/Year } \\
\text { /Title }\end{array}$ & Publisher & Field & $\begin{array}{l}\text { Count } \\
\text { ry }\end{array}$ & $\begin{array}{l}\text { Research } \\
\text { Purpose }\end{array}$ & $\begin{array}{l}\text { Research } \\
\text { Approach }\end{array}$ & $\begin{array}{l}\text { Findings } \\
\text { on } \\
\text { Teachers } \\
\text { ' } \\
\text { Follower } \\
\text { ship } \\
\text { Styles }\end{array}$ \\
\hline 3 & $\begin{array}{l}\text { Al-Anshory } \\
\text { (2014) - The } \\
\text { gap between } \\
\text { primary and } \\
\text { secondary } \\
\text { schools' } \\
\text { teachers in } \\
\text { followership } \\
\text { styles at Adni } \\
\text { Islamic } \\
\text { School, } \\
\text { Malaysia }\end{array}$ & $\begin{array}{l}\text { Unpublish } \\
\text { ed master } \\
\text { dissertatio } \\
\mathrm{n}\end{array}$ & $\begin{array}{l}\text { Religion } \\
\text { School }\end{array}$ & $\begin{array}{l}\text { Malay } \\
\text { sia }\end{array}$ & $\begin{array}{l}\text { To } \\
\text { investigate } \\
\text { the gap } \\
\text { between } \\
\text { primary and } \\
\text { secondary } \\
\text { school } \\
\text { teachers in } \\
\text { followership } \\
\text { style at Adni } \\
\text { Islamic } \\
\text { School, } \\
\text { Malaysia. }\end{array}$ & $\begin{array}{l}\text { A } \\
\text { quantitativ } \\
\text { e study } \\
\text { using Kelley } \\
\text { (1992) } \\
\text { Followershi } \\
\text { p } \\
\text { Questionna } \\
\text { ire } \\
\text { completed } \\
\text { by primary } \\
\text { and } \\
\text { secondary } \\
\text { school } \\
\text { teachers } \\
\text { (n=92) at } \\
\text { Adni } \\
\text { Islamic } \\
\text { School, } \\
\text { Malaysia. }\end{array}$ & $\begin{array}{l}\text { Exemplar } \\
y=42.3 \% \\
\text { Alienate } \\
d=6.5 \% \\
\text { Pragmati } \\
\text { st= } \\
26.1 \% \\
\text { Conformi } \\
\text { st= } \\
16.3 \% \\
\text { Passive= } \\
8.7 \%\end{array}$ \\
\hline 4 & $\begin{array}{l}\text { Francis } \\
\text { (2015) } \\
\text { Followership } \\
\text { Among } \\
\text { Secondary } \\
\text { School } \\
\text { Teachers }\end{array}$ & $\begin{array}{l}\text { Unpublish } \\
\text { ed } \\
\text { doctoral } \\
\text { dissertatio } \\
\mathrm{n}\end{array}$ & $\begin{array}{l}\text { Second } \\
\text { ary } \\
\text { School }\end{array}$ & UK & $\begin{array}{l}\text { To explore } \\
\text { the } \\
\text { followership } \\
\text { of } \\
\text { schoolteach } \\
\text { ers working } \\
\text { in the } \\
\text { secondary } \\
\text { education } \\
\text { sector }\end{array}$ & $\begin{array}{l}\text { A mixed } \\
\text { method } \\
\text { study: used } \\
\text { biographica } \\
\text { l-style } \\
\text { interviews } \\
\text { ( } n=15) \text { to } \\
\text { understand } \\
\text { why } \\
\text { teachers } \\
\text { follow, } \\
\text { reveal } \\
\text { factors that } \\
\text { have } \\
\text { shaped the } \\
\text { agency of } \\
\text { schoolteac } \\
\text { hers that } \\
\text { influence } \\
\text { their }\end{array}$ & $\begin{array}{l}\text { Exemplar } \\
y=86 \% \\
\text { Alienate } \\
d=0 \\
\text { Pragmati } \\
\text { st }=14 \% \\
\text { Conformi } \\
\text { st }=0 \\
\text { Passive }= \\
0\end{array}$ \\
\hline
\end{tabular}




\begin{tabular}{|c|c|c|c|c|c|c|c|}
\hline $\begin{array}{l}\mathrm{N} \\
\mathbf{0}\end{array}$ & $\begin{array}{l}\text { Author/Year } \\
\text { /Title }\end{array}$ & Publisher & Field & $\begin{array}{l}\text { Count } \\
\text { ry }\end{array}$ & $\begin{array}{l}\text { Research } \\
\text { Purpose }\end{array}$ & $\begin{array}{l}\text { Research } \\
\text { Approach }\end{array}$ & $\begin{array}{l}\text { Findings } \\
\text { on } \\
\text { Teachers } \\
\text {, } \\
\text { Follower } \\
\text { ship } \\
\text { Styles } \\
\end{array}$ \\
\hline & & & & & & $\begin{array}{l}\text { journeys to } \\
\text { followershi } \\
\text { p. The } \\
\text { study also } \\
\text { administer } \\
\text { ed Kelley's } \\
\text { (1992) } \\
\text { Followershi } \\
p \\
\text { Questionna } \\
\text { ire in order } \\
\text { to } \\
\text { understand } \\
\text { how } \\
\text { teachers } \\
\text { follow } \\
\text { ( } n=69 \text { ). }\end{array}$ & \\
\hline 5 & $\begin{array}{l}\text { Hinić (2017) - } \\
\text { Followership } \\
\text { Styles and } \\
\text { Job } \\
\text { Satisfaction } \\
\text { in Secondary } \\
\text { School } \\
\text { Teachers in } \\
\text { Serbia }\end{array}$ & $\begin{array}{l}\text { Education } \\
\text { al } \\
\text { Managem } \\
\text { ent } \\
\text { Administr } \\
\text { ation \& } \\
\text { Leadershi } \\
\text { p }\end{array}$ & $\begin{array}{l}\text { Second } \\
\text { ary } \\
\text { Schools }\end{array}$ & Serbia & $\begin{array}{l}\text { To } \\
\text { determine } \\
\text { the } \\
\text { frequency } \\
\text { of } \\
\text { followership } \\
\text { styles, and } \\
\text { their } \\
\text { connection } \\
\text { with job } \\
\text { satisfaction } \\
\text { and } \\
\text { satisfaction } \\
\text { with } \\
\text { extrinsic/int } \\
\text { rinsic } \\
\text { aspects of } \\
\text { work in } \\
\text { teachers }\end{array}$ & $\begin{array}{l}\text { A } \\
\text { quantitativ } \\
\text { e study } \\
\text { using Kelley } \\
\text { (1992) } \\
\text { Followershi } \\
p \\
\text { Questionna } \\
\text { ire } \\
\text { completed } \\
\text { by } \\
\text { secondary } \\
\text { school } \\
\text { teachers of } \\
\text { three } \\
\text { grammar } \\
\text { and three } \\
\text { vocational } \\
\text { schools in } \\
\text { three } \\
\text { towns in } \\
\text { Serbia } \\
\text { (n=206). }\end{array}$ & $\begin{array}{l}\text { Exemplar } \\
\mathrm{y}=58.7 \% \\
\text { Alienate } \\
\mathrm{d}=1 \% \\
\text { Pragmati } \\
\mathrm{st}= \\
39.8 \% \\
\text { Conformi } \\
\text { st }=0.5 \% \\
\text { Passive= } \\
0\end{array}$ \\
\hline
\end{tabular}




\begin{tabular}{|c|c|c|c|c|c|c|c|}
\hline $\begin{array}{l}\mathbf{N} \\
\mathbf{0}\end{array}$ & $\begin{array}{l}\text { Author/Year } \\
\text { /Title }\end{array}$ & Publisher & Field & $\begin{array}{l}\text { Count } \\
\text { ry }\end{array}$ & $\begin{array}{l}\text { Research } \\
\text { Purpose }\end{array}$ & $\begin{array}{l}\text { Research } \\
\text { Approach }\end{array}$ & $\begin{array}{l}\text { Findings } \\
\text { on } \\
\text { Teachers } \\
\text {, } \\
\text { Follower } \\
\text { ship } \\
\text { Styles } \\
\end{array}$ \\
\hline 6 & $\begin{array}{l}\text { Mimick } \\
\text { (2018) } \\
\text { Examining } \\
\text { Followership } \\
\text { Styles and } \\
\text { Job } \\
\text { Satisfaction } \\
\text { in Public, } \\
\text { Midwestern } \\
\text { K-12 } \\
\text { Teachers }\end{array}$ & $\begin{array}{l}\text { Unpublish } \\
\text { ed } \\
\text { doctoral } \\
\text { dissertatio } \\
\mathrm{n}\end{array}$ & $\begin{array}{l}\text { Public } \\
\text { K-12 } \\
\text { School }\end{array}$ & USA & $\begin{array}{l}\text { To } \\
\text { determine if } \\
\text { differences } \\
\text { existed in } \\
\text { perceived } \\
\text { job } \\
\text { satisfaction } \\
\text { of K-12 } \\
\text { teachers } \\
\text { from the } \\
\text { same } \\
\text { Midwest } \\
\text { district } \\
\text { based on } \\
\text { followership } \\
\text { styles }\end{array}$ & $\begin{array}{l}\text { A } \\
\text { quantitativ } \\
\text { e study } \\
\text { using } \\
\text { Kelley's } \\
\text { (1992) } \\
\text { followershi } \\
\text { p style } \\
\text { questionnai } \\
\text { re and } \\
\text { Weiss et } \\
\text { al.'s (1967) } \\
\text { short-form } \\
\text { Minnesota } \\
\text { satisfaction } \\
\text { questionnai } \\
\text { re } \\
\text { completed } \\
\text { by teachers } \\
\text { via } \\
\text { Qualtrics } \\
\text { (n=105). }\end{array}$ & $\begin{array}{l}\text { Exemplar } \\
y=69.5 \% \\
\text { Alienate } \\
d=3.8 \% \\
\text { Pragmati } \\
\text { st }= \\
24.8 \% \\
\text { Conformi } \\
\text { st }=1.9 \% \\
\text { Passive= } \\
0\end{array}$ \\
\hline 7 & $\begin{array}{l}\text { Hicks (2018) - } \\
\text { An } \\
\text { Exploratory } \\
\text { Study of } \\
\text { Followership } \\
\text { in New } \\
\text { Hampshire } \\
\text { High Schools }\end{array}$ & $\begin{array}{l}\text { Unpublish } \\
\text { ed } \\
\text { doctoral } \\
\text { dissertatio } \\
\mathrm{n}\end{array}$ & $\begin{array}{l}\text { High } \\
\text { school }\end{array}$ & USA & $\begin{array}{l}\text { To explore } \\
\text { followership } \\
\text { theory and } \\
\text { its practical } \\
\text { application } \\
\text { in New } \\
\text { Hampshire } \\
\text { public high } \\
\text { schools }\end{array}$ & $\begin{array}{l}\text { A mixed- } \\
\text { method } \\
\text { study using } \\
\text { modified } \\
\text { Kelley } \\
\text { (1992) } \\
\text { Followershi } \\
\text { p } \\
\text { Questionna } \\
\text { ire and two } \\
\text { open- } \\
\text { ended sub- } \\
\text { questions } \\
\text { completed } \\
\text { by high- } \\
\text { school } \\
\text { teachers }\end{array}$ & $\begin{array}{l}\text { Exemplar } \\
\mathrm{y}=76.4 \% \\
\text { Alienate } \\
\mathrm{d}=0 \\
\text { Pragmati } \\
\mathrm{st}= \\
14.8 \% \\
\text { Conformi } \\
\text { st }=8.7 \% \\
\text { Passive= } \\
0\end{array}$ \\
\hline
\end{tabular}


INTERNATIONAL JOURNAL OF ACADEMIC RESEARCH IN BUSINESS AND SOCIAL SCIENCES Vol. 11, No. 2, 2021, E-ISSN: 2222-6990 @ 2021 HRMARS

\begin{tabular}{|l|l|l|l|l|l|l|}
\hline $\begin{array}{l}\text { N } \\
\text { o }\end{array}$ & $\begin{array}{l}\text { Author/Year } \\
\text { /Title }\end{array}$ & Publisher & Field & $\begin{array}{l}\text { Count } \\
\text { ry }\end{array}$ & $\begin{array}{l}\text { Research } \\
\text { Purpose }\end{array}$ & $\begin{array}{l}\text { Findings } \\
\text { Research } \\
\text { Approach }\end{array}$ \\
& & & & & $\begin{array}{l}\text { Teachers } \\
\text { Tollower } \\
\text { Fhip } \\
\text { Styles }\end{array}$ \\
\hline & & & & & $\begin{array}{l}\text { (n=559) via } \\
\text { email. }\end{array}$ & \\
& & & & & & \\
\end{tabular}




\section{Comparison of Western vs Non-Western Teachers' Followership Styles in Schools}

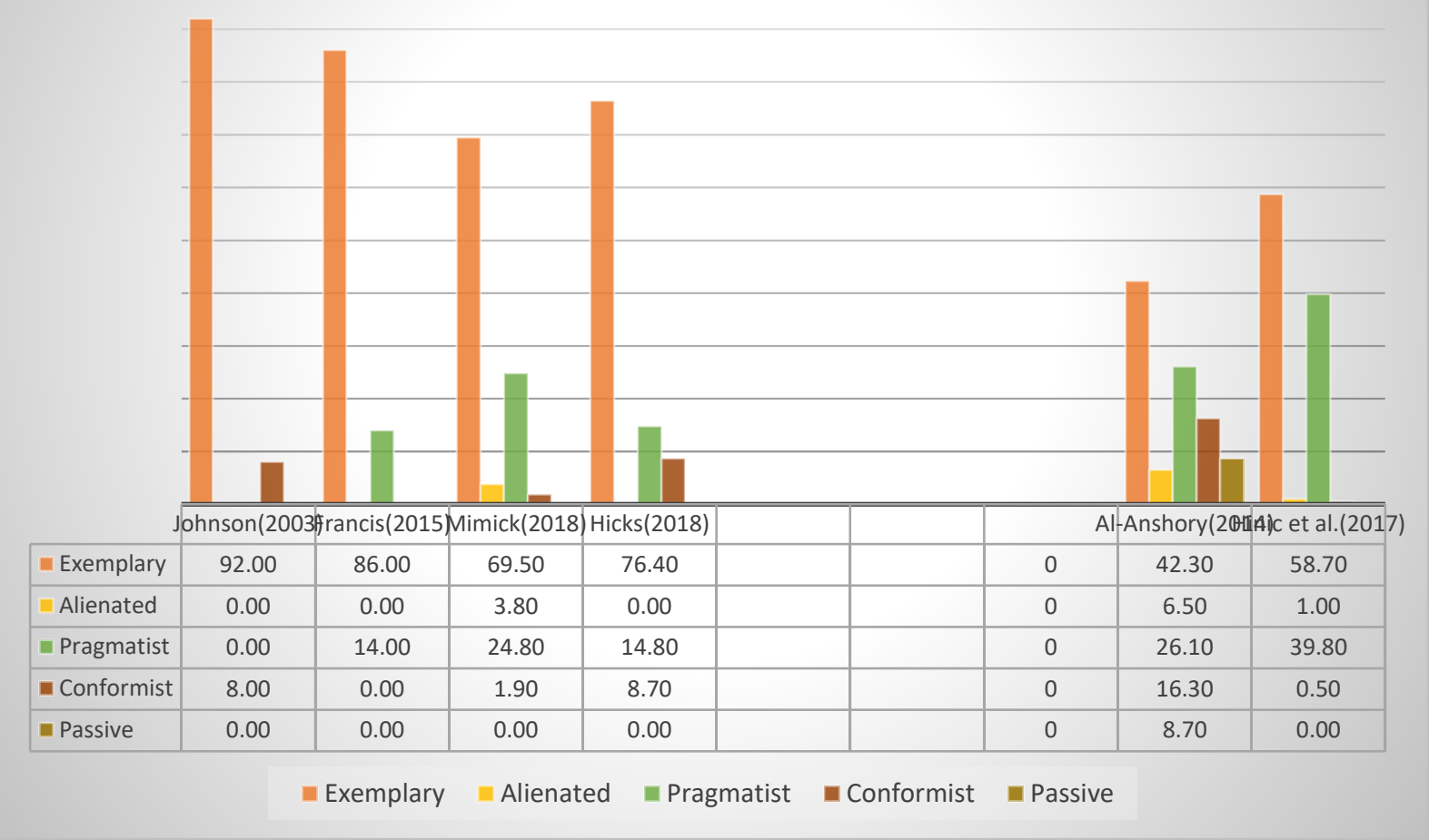

Figure 1. Comparison of Western vs Non-Western Teachers' Followership Styles in Schools

A snapshot of the comparison between Western and Non-Western teachers' followership styles in school settings is illustrated in Figure 1. Obviously, both Western and non-Western literatures have uncovered similarities and differences in teachers' followership styles practised in schools. Although the findings are not typically the same, most of the Western studies demonstrated majority of the teachers are practising exemplary followership styles. However, this scenario is slightly different in Non-Western context. Despite both research in Malaysia and Serbia reported higher percentage of exemplary followers in schools, pragmatist followership styles, however, contribute significantly to the overall typology. According to the literature, the differences in these results might be attributed to different culture context in both regions. The Non-Western country with the high-power distance may cause the teachers to obey without challenging as they tend to be "good citizen" and preventing "unnecessary misunderstandings" (Walker et al., 2012; Zheng et al., 2019).

Despite the differences, the findings from both regions of country have not reported any passive followers in schools. This is not the same as reported by Kelley (1992) in corporate where he estimated $5-10 \%$ of followers are categorised as passive followers (see Table 3). The reason could be teachers are knowledge workers who have more commitment and aware about their responsibilities. Also, the educational background and experience as teachers' classroom leaders that contribute to variation in their role as followers as compare to other industries (Hicks, 2018). 
Table 3. Percentage of Followership Types in Non-Education Organizations

\begin{tabular}{ll}
\hline Type & Percent \\
\hline Passive & $5-10 \%$ \\
Alienated & $15-25 \%$ \\
Conformist & $20-30 \%$ \\
Pragmatist & $25-35 \%$ \\
Exemplary & $5-10 \%$ \\
\hline
\end{tabular}

Note: Adapted from Kelley, R.E. (1992). The power of followership: How to create leaders people want to follow... and followers who lead themselves. New York: Doubleday.

In conclusion, the analysis of past research results leads to some valuable insight, the most important of which is to understand that followership is not passive or literally delegated, but rather a role chosen by those individuals who dedicate themselves to a mission, a job task, a group goal, or a mutual desire for an outcome. Today, the emergence in educational leadership has evolved to recognize teachers' contributions as a critical part of successful schools. Owing to the increasing prevalence of the importance of the followership role in the leadership process, it is therefore essential to analyse teachers' followership styles in school settings.

\section{The Importance of Followership in Schools}

Encouragingly, after many years of promoting heroic, charismatic, transformational leaders to shape the success of one's leadership, scholars diverted their interest to followership. Scholars are increasingly aware that followership is an integral part of leadership theory and practise (Kellerman, 2008). Extensive evidence has shown that by fostering leader-follower dynamic, leaders are able to strengthen their leadership effectiveness (Shamir, 2012; UhlBien et al., 2014). If school is in a time of chaos, uncertainty and continual transition, the situation will become far too complicated for the principals to run the school on their own. As a result, empowering follower (teachers) to share the burden and responsibility of bringing the school to success has been one of the key challenges facing the principals today. New age teachers are expected to play a contemporary role, such as demonstrating commitment to shared goals, more participation in school management decision-making, being proactive in teaching process and school improvement programmes, displaying high quality team collaboration and being able to contribute to school (Schweinberger \& Huber, 2018).

Followership notion shifts the focus on leadership by arousing followership element in the leadership equation, especially in knowledge industries such as school. Looking at the nature of teaching profession, schools offer a fascinating environment for followership study. How to implement followership theory effectively becomes a challenging task to school leaders. As suggested by a well-known Austrian-born American management consultant, Peter Drucker (2002): "the only way to achieve leadership in the knowledge-based business is to spend time with promising knowledge professionals: to get to know them and to be known by them; to mentor them and to listen to them; to challenge them and to encourage them" (p.12). The Wallace Foundation (2013) also reports that followers (i.e., teachers) in knowledge industry are precious assets whom leaders must take advantage of their capability and central role to enhance the school performance. Thus, leaders must respect their 
reciprocal relationship with teachers and acknowledge teachers as knowledge workers who play a vital role in student achievement that determine school success.

Teachers with good followership equipped schools in achieving the desired goals. Indeed, teachers in this new era are well educated, acquire skills that compatible with their leaders and exhibit leadership abilities in classrooms. Hauge et al. (2014) articulate that today's schools are "entirely dependent on the teachers - especially their competencies and motivations for teaching and learning - to fulfil the overall aims of the school" (p.358). Hauge et al. (2014) further describe the relationship between leaders and teachers as a "mutual dependency" that "is fundamental for understanding the complexities of leadership and educational change" (p. 359). Although many accepted that schools could not excel without teachers, traditionally school leaders rarely pay attention to teachers in the field of education leadership.

Put another way, educational research has made a considerable effort to identify and analyse educational leadership in relation to leadership styles and models (e.g., instructional leadership, transformational leadership). Given the contributions to school performance and students' academic achievement, the school prides itself on the ability to present many different styles of leadership. Leadership skills among school leaders are always at the top of the list that highlighted by many training programs, especially at conferences. Though scholars propose that it stands an acute reason to prepare the next generation of leadership, a critical link is obviously still lacking in that part of professional development - followership.

The significance of the power of followership has begun to attract concern from academicians and practitioners. It is therefore necessary to cultivate the followership notion and raise awareness of the follower role among teachers, especially during the period of the COVID-19 pandemic. School leaders and followers might not have the opportunity to meet each other, rather than relying on proactive teachers to perform their duties to ensure that students learn. In time, schools really need followers who can demonstrate independent critical thinking and who are able to engage actively in all school events to improve and sustain school performance.

\section{Conclusion}

Today's school structure has evolved to a flatter, more collaborative and democratic environments, the school principals need to truly understand and appreciate the differences among the followers (i.e., teachers) in order to manage their human resource effectively. Dyadic relationships between leaders and followers may be strengthened via cultivation and enactment of good followership. This will then shape the development of pragmatic strategies that help promote leadership effectiveness. As such, it is now more urgent than ever to examine the dynamic relationship between the school principals and the teachers to generate awareness of the value of the role of followership as a core determinant of performance in the organisation. Apparently, the time has come for scholars and practitioners to "reverse their lens" (Lapierre \& Bremner, 2010; Shamir, 2007; Xu et al., 2019) and make their way to follower-centric studies in the field of educational leadership research.

\section{Future Agenda}

Notably, followership notion has gradually gained attention in educational research as a trendy concept nowadays. Scholars begin to perceive followership as a distinct role in the dynamic relationship between school leaders and teachers (Crippen, 2012; Cruickshank, 
2017). The concept of followership has been placed under scrutiny to enhance leadership effectiveness by all the leaders (Henry, 2012; Shondrick \& Lord, 2010). In general, scholars believe that teachers who reinforce the human dynamic relationship in school could help to promote a transparent, inclusive, and more comprehensive interaction in the organizations (Crippen, 2012). Obviously, both school leaders and teachers will benefit from reflecting on the importance of establishing a dignified leader-follower relationship. Therefore, the empowerment of teachers has been the most imperative challenge that school leaders need to learn, improvise, and execute.

\section{Acknowledgement}

The authors wish to thank the Hadiah Latihan Persekutuan (HLP), Ministry of Education Malaysia and Universiti Malaysia Sarawak for the support in carry out this study.

\section{References}

Al-Anshory, A. S., \& Ali, M. H. (2014). The Gap between Primay and Secondary School Teacher Followership Styles at Adni Islamic School, Malaysia. IIUM Journal of Educational Studies, 2(2), 59-83. https://doi.org/10.31436/ijes.v2i2.50

Bufalino, G. (2018a). Followership under the spotlight: implications for followership development. Industrial and Commercial Training, 50(2), 55-60. https://doi.org/10.1108/ICT-04-2017-0028

Bufalino, G. (2018b). We need great "followers", not just great leaders: a brief questionnaire for followership development. Development and Learning in Organizations, 32(1), 1-3. https://doi.org/10.1108/DLO-04-2017-0040

Carsten, M. K. (2017). Followership Development: A Behavioral Approach. In Leader Development Deconstructed. https://doi.org/10.1007/978-3-319-64740-1

Carsten, M. K., Uhl-Bien, M., \& Griggs, T. L. (2016). Do you believe what i believe? A theoretical model of congruence in follower role orientation and its effects on manager and subordinate outcomes. Research in Occupational Stress and Well Being. https://doi.org/10.1108/S1479-355520160000014004

Carsten, M. K., Uhl-Bien, M., West, B. J., Patera, J. L., \& McGregor, R. (2010). Exploring social constructions of followership: A qualitative study. Leadership Quarterly. https://doi.org/10.1016/j.leaqua.2010.03.015

Chaleff, I. (2008). The Courageous Follower-Standing Up To and For our Leaders (2nd Edition). Berrett-Koehler Publishers. https://doi.org/10.1017/CBO9781107415324.004

Clarke, M., Killeavy, M., \& Ferris, R. (2015). Mentor teachers as leaders and followers in school-based contexts in the Republic of Ireland. International Journal of Educational Management. https://doi.org/10.1108/IJEM-09-2013-0142

Crippen, C. (2012). Enhancing authentic leadership-followership: Strengthening school relationships. Management in Education, 26(4), 192-198. https://doi.org/10.1177/0892020612439084

Crossman, B., \& Crossman, J. (2011). Conceptualising followership - a review of the literature. Leadership, 7(4), 481-497. https://doi.org/10.1177/1742715011416891

Cruickshank, V. (2017). Followership in the School Context. Open Journal of Leadership, 06(03), 95-103. https://doi.org/10.4236/ojl.2017.63006

Drucker, P. F. (2002). They're not employees, they're people. In Harvard Business Review.

Du, Y., Xu, L., Xi, Y. M., \& Ge, J. (2019). Chinese leader-follower flexible interactions at varying leader distances: An exploration of the effects of followers in school cases. Chinese 
Management Studies, 13(1), 191-213. https://doi.org/10.1108/CMS-03-2018-0461

Eadm, D. B., \& Kellerman, B. (2018). How Followers Are Creating Change.

Foti, R. J., Hansbrough, T. K., Epitropaki, O., \& Coyle, P. T. (2017). Dynamic viewpoints on implicit leadership and followership theories: Approaches, findings, and future directions. Leadership Quarterly, 28(2), 261-267. https://doi.org/10.1016/j.leaqua.2017.02.004

Ghias, W., \& Hassan, S. (2018). Does Courageous Followership contribute to Exemplary Leadership Practices: Evidence from Pakistan ? International Journal of Business \& Management, June, 10-21. https://doi.org/10.13140/RG.2.2.13212.80009

Gronn, P. (1999). Substituting for leadership: The neglected role of the leadership couple. Leadership Quarterly. https://doi.org/10.1016/S1048-9843(99)80008-3

Gronn, P., \& Ribbins, P. (1996). Leaders in Context: Postpositivist Approaches to Understanding Educational Leadership. Educational Administration Quarterly. https://doi.org/10.1177/0013161X96032003008

Hauge, T. E., Norenes, S. O., \& Ved øy, G. (2014). School leadership and educational change: Tools and practices in shared school leadership development. Journal of Educational Change, 15(4), 357-376. https://doi.org/10.1007/s10833-014-9228-y

Henry, B. C. (2012). Leadership Models for Effective Change Management. International Journal of Computer Science and Management Research, 1(4), 817-819.

Hinić, D., Grubor, J., \& Brulić, L. (2017). Followership styles and job satisfaction in secondary school teachers in serbia. Educational Management Administration and Leadership, 45(3), 503-520. https://doi.org/10.1177/1741143215623787

Hutton, D. M. (2018). Critical factors explaining the leadership performance of highperforming principals. International Journal of Leadership in Education, 21(2), 245-265. https://doi.org/10.1080/13603124.2016.1142118

Kellerman, B. (2008). Followership. How Followers are Creating Change and Changing Leaders. Harvard Business Press. https://doi.org/10.1108/dlo.2009.08123fae.001

Kellerman, B. (2016). Leadership-it's a system, not a person! Daedalus, 145(3), 83-94. https://doi.org/10.1162/DAED_a_00399

Kelley, R. E. (1988). In Praise of Followers Harvard Business Review. In Harvard Business Review (p. 4). http://www.kquattrin.com/uploads/2/5/8/7/25876455/kelley_1988.pdf

Kelley, R. E. (1992). The power of followership: How to create leaders people want to follow, and followers who lead themselves. Doubleday.

Kilburn, brandon R. (2010). Who are we leading? International Journal of the Academic Business World, 1(5), 861-870.

Lapierre, L. M., \& Bremner, N. (2010). Reversing the Lens: How Can Followers Influence Their Leader's Behavior? Annual Meeting of the Academy of Management, August.

Lemma, T. (2018). Teachers' perception of the Effectiveness of Leadership in Cheha Woreda Secondary and Preparatory Schools of Guraghe Zone.

Mertler, C. A. ., Steyer, S., \& Petersen, G. J. (1997). Teachers' Perceptions of the Leadership/Followership Dialectic. papers3://publication/uuid/A0A266F4-18E4-41C4B1F6-EDFB58C6E8CE

Schweinberger, K., \& Huber, B. (2018). Followership in education requires experience. A comparison of compulsory and vocational schools. Swiss Journal of Educational Science, 40(2), 485-502. https://doi.org/10.24452/sjer.40.2.5071

Shamir, B. (2007). Follower-centered perspectives on leadership: A tribute to the memory of James R. Meindl. 
Shamir, B. (2012). Leadership in Context and Context in Leadership Studies. In The Oxford Handbook of Leadership.

Shondrick, S. J., \& Lord, R. G. (2010). Implicit leadership and followership theories: Dynamic structures for leadership perceptions, memory, leader-follower processes. International Review of Industrial and Organizational Psychology 2010, 25, 1-33. https://doi.org/10.1002/9780470661628.ch1

Thannimalai, R. (2020). Teachers Followership towards School Principal's Leadership : A Qualitative Approach Teachers Followership towards School Principal's Leadership : A Qualitative Approach. International Journal of Instruction, Technology \& Social Sciences, 1(1), 24-37.

Thody, A. (2000). Followership or Followersheep? An Exploration of the Values of NonLeaders. Management in Education, 14(2), 15-18. https://doi.org/10.1177/089202060001400205

Thody, A. (2003). Followership in Educational Organizations: A Pilot Mapping of the Territory. Leadership and Policy in Schools, 2(2), 141-156. https://doi.org/10.1076/lpos.2.2.141.15542

Tsakeni, M., \& Jita, L. (2017). Followership and sustainability of school leadership for Science and Mathematics: A distributive perspective. Journal of Education (University of KwaZulu-Natal), 69, 237-256.

Uhl-Bien, M., Riggio, R. E., Lowe, K. B., \& Carsten, M. K. (2014). Followership theory: A review and research agenda. Leadership Quarterly, 25(1), 83-104. https://doi.org/10.1016/j.leaqua.2013.11.007

Walker, A., Hu, R., \& Qian, H. (2012). Principal leadership in China: An initial review. School Effectiveness and School Improvement, 23(4), 369-399. https://doi.org/10.1080/09243453.2012.678863

Wallace Foundation. (2013). The School Principal as Leader: Guiding Schools to Better Teaching and Learning. http://www.wallacefoundation.org/knowledge-center/schoolleadership/effective-principal-leadership/Documents/The-School-Principal-as-LeaderGuiding-Schools-to-Better-Teaching-and-Learning.pdf

Warfield, K., Young, W., \& Gill, S. (2019). Leadership and Followership: The Yin \& Yang to Building Professional Capacity. 6(August). http://www.icpel.org

Xu, A. J., Loi, R., Cai, Z., \& Liden, R. C. (2019). Reversing the lens: How followers influence leader-member exchange quality. Journal of Occupational and Organizational Psychology. https://doi.org/10.1111/joop.12268

Zheng, X., Yin, H., \& Li, Z. (2019). Exploring the relationships among instructional leadership, professional learning communities and teacher self-efficacy in China. Educational Management Administration and Leadership. https://doi.org/10.1177/1741143218764176 